\title{
Political performance as a technology of influence
}

UDC 321.728

DOI https://doi.org/

10.24195/2414-9616-2018-1-66-70

Makarenko Liliia Petrivna

Candidate of Political Science,

Doctoral Student at the Department

of Political Science

of the Taras Shevchenko National

University of Kyiv

Volodymyrska Str., 64/13, Kyiv, Ukraine
The article examines political performance as a form of social protest, as well as a means of supporting mostly epic image of politicians. It is clarified the features and conditions of efficiency of the political performance. Among the features, the key place is devoted to the entertainment. It appeals to the emotions and involvement in the performance of the audience. Among the conditions of effectiveness - the relevance of the action, as a rule, the protest nature of the act with a certain aesthetics and shock, the clarity of the content of the campaign for the audience. The conclusion is that theatricalization and "designing" of political reality will become increasingly important for the modern political process, and the perception of political events through the prism of entertainment will inevitably come to new forms and scales. Key words: political performance, technology of influence, protest, image, theatricalization of politics.
Introduction. Political performance - is a relatively new subject of study in Ukrainian political science, despite the fact that it has been used in political practice since ancient times. Some aspects of the problem are highlighted in the works of U. Ilnitskaya, T. Kremen, G. Pocheptsov, N. Khomi.

Goal of the article. However, in recent years, political performance has firmly established itself as a form of social protest, as well as a means of forming and maintaining an image, thereby proving its effectiveness as a technology of influence. In consequence of this aspect we intend to analyze it.

Main material. The concept came from the art sphere, which denotes the form of action-oriented art, in which the work is the actions of the author, which viewers are watching in the real time.

In English, the term "performance" has many meanings: action, spectacle, ritual sight, performance, concert, as well as trick and focus.

Professor of New York University R. Schehner defines it as a certain purposeful action, which is demonstrated by representatives of one social group to another and is realized, as a rule, through game and ritual elements of communication [10, p. 28].

He tries to find out the general features of the performance, bringing them either from the rituals, or from the behavior of animals.

By the types of the rules, he distinguishes between three varieties of performances. A game is characterized by the fact that the rules are offered by the one playing. Regarding a sports game or theater, the rules determine what can be done and what can't be done. A ritual has rules that are higher than the person who obeys them. R. Schehner brings together the ritual and the game in contrast to sports games and theater.

The boundary between performance and ordinary life is rather conditional. In this opinion, R. Schehner is close to the theories of $\mathrm{M}$. Evreinov and his idea of theatricality of our lives. He saw this theatricality both in the usual reception of guests, and in the colorful dress of the natives.
By dividing the audience into an integrated and random, $\mathrm{R}$. Schehner noticed that a random audience is more interested in acting for the following reasons:

1) the random audience had a choice; it came, paying the money for the performance;

2) its members came by themselves, so mass actions are impossible, because the viewer feels strangers among the others;

3) an integrated audience knows in advance what will happen;

4) ritual performances often last so long that it is simply not enough to be interested all the time, performances for a random audience are arranged in special time intervals $[10$, c. 37$]$.

We can get the knowledge about the performance in the writings of the theorists and practitioners of the early 20th century theater, especially M. Yevreinov and V. Meyerhold. They sought to intensify the theatrical performance by the efforts of the actors, and the active participation of the viewer, thinking them as the only communicative structure, that led to the foundation of the today's performances.

M. Yevreinov defended "theatrokratia" ("dominating the theater above us"), seeking everywhere signs of creative change of the world by man. A child can play, for example, with a button, adults are interested in a new form of playing cards. The permission of Emperor Paul to wear round hats, M. Yevreynov notes, has caused more pleasure in St. Petersburg than the abolition of the secret police.

On the pages of his three-volume study "Theater for yourself", he cites a large number of examples of "theatrical instinct" of people. We all are - actors, even for ourselves, says M. Evreinov [4].

German political scientists T. Meier and M. Kampmann $[14 ; 15]$, say that the key role in theatricalization of political activity is directed by the media, which in the era of the globalization of communicative processes have become, in fact, electronic developments for politicians-actors.

An American researcher, A. Borecca, notes that politics becomes a theater when it politicians are 
given a stage where they can observe the audience, and when the participation of the spectator - the requirement of the production on the stage, becomes the norm of political interaction [13, c. 66].

Many researchers believe that politics and theater are similar because there is a need for an audience in both cases, an attempt is being made to conquer this audience. Therefore, the result of the unity of purpose is the unity of means. And a very important role in this is played by the mass media, which are turning into a stage for performances. An example of this is the speeches of politicians on television: an appeal to the people, participation in political talk shows, election debates, etc. The main goal of political performance is not the communicative act itself, but the gain of the audience's attention. After all, political choice by many is carried out not after a weighed analysis, but under the influence of an emotional impression.

U. Initska calles a certain theatricalization of reality as an important aspect of political performances spectacle [1, c. 194]. Among the examples are the inauguration of the president, the coronation of the monarch, military parades, airshows, the assignment of military ranks, solemn meetings of parliaments, festive rallies, demonstrations, court hearings (with judge mantle), etc.

$\mathrm{N}$. Homa denies the ideas of the previous author, believing that it is necessary to distinguish between political performance and political ritual, which include the given examples. Unlike rituals in the performance, the boundaries between the viewer and the actor are erased, creative zigzags are encouraged (for example, passers-by are involved). The emphasis is made on the interaction between the scene and the audience hall, which is impossible in the event of a solemn political ritual. Performance is a complex communicative action, in which the role of actors and the audience themselves are equally important. The essence of the performance is manifested in its function of manifestation of political ideas and the demonstration of the role of its supporters [11].

T. Kremen believes that through the performances of political mobilization reaches apolitical strata of the population, involves them in political activity by providing political participation of elements of the game [2, c. 72]. The researcher gives an example of effective political mobilization through social networks, due to their emotional background. She believes that performance does not hand spontaneity. It has an organization and a clear hierarchy. It pursues certain goals and is not intended for casual viewers. Organizers choose a place and time with the purpose of the greatest influence on the audience. Using political performance gives a certain guarantee of attracting the audience to political problems, predictability, the basis modeling of political activity.

Performance has always played a special role in society: for example, in ancient times it was thought that it would be crop failure if do not hold the ritual and do not call for the help of the force of nature.
The performance can be considered as the ritual of the dedication to the Cossacks. Official enrollment in the Cossacks was carried out through the ritual of admission. The newcomer, who passed all the tests, turned to the ataman, bowed to him and asked to be accepted into a partnership. According to the custom, the ataman asked for the consent of the chef of the Kuren, and when he agreed, the newcomer paid the cook a certain amount of money and had to bring to the ceremony guarantors - the prominent Cossacks who knew him well. The ruling of the ceremony commission was asserted by the Ataman.

Today, a lot of real events are dramatized so that they can get on TV screens. These are terrorist acts, theft, demonstrations, even press conferences. Unidentified individuals and usually silent groups have the opportunity to get communicative power when they do something worthy of news. Negotiations between them and the authorities always take place in the eyes of the third party - the viewer.

Performances are used for any political regime. "Performance is becoming a central form both during the period of "decay" of society and in the period of rapid changes. And in both cases, performances allow us to produce a unified interpretation of the reality" [11].

If we talk about totalitarianism, the most common varieties of performance were demonstrations, parades, solemn gatherings. They existed as the only model of correct mass behavior. The space where the performance took place, clearly distinguished between "simple" and "special". The right to the last (the tribune, the presidium) was only elected. Demonstration and parade used the movement as its component. Accordingly, the symbolic significance acquired the direction of movement, the column could go only as it was defined. When in Kiev the direction of the movement of colonies passed by the rostrum was changed, a joke appeared immediately: they say, 70 years we went by incorrect way. The solemn assembly reproduced the same model of demonstration, but it unfolded in the report proclaimed by the member of the Politburo. It was devoted exclusively to the successes and represented the verbalization of the column that was passing by the rostrum.

In totalitarian performances all participated. Interestingly, everyone understood the insincerity and artificiality of these structures. But performance is possible only when the audience adopts its rules.

Totalitarian performances were replaced by non-totalitarian - there were rallies and demonstrations. But it's interesting that the laws of the performance do not change. New presidential performances began to be developed - receptions of ambassadors, appeals to the people, etc. The non-verbal sphere is rather quickly ritualized, repeating the same patterns.

A new type of performance became parliamentary battles. On the one hand, they demonstrate elements of independence from the authorities, sometimes 
arguing with the president, ministers. On the other hand, all real decisions are clearly defined before voting in the session hall.

Let's recall the first parliamentary meetings in the USSR, that were a really good performances. People did not get of the TVs. Subsequently, the same attention was paid to the election of the Speaker of the Verkhovna Rada when former dissidents who became deputies claimed to be leaders. But it was an expressive performance, since they had no real chances. The theater has surpassed politics at the same time.

One of the varieties of performance was the Party congresses. This is the sample of the performance, because its end is clearly defined and necessarily fulfilled. There is an integrated audience. Existing and habitual behavior patterns, clear structuring of space and time. This is political communication, where the issues of power processes are solved. And since the power falls into one hand - the masses are sometimes needed only to legitimize this process. Indeed, the processes of decision-making and legitimation are different, and at the last time is easier to implement, directing it to the performance.

Political performance is an essential element of a democratic structure, since it allows one to join democracy to a wide circle of people. Political performances sometimes bring up a new type of personality. After all, most of our people's deputies "grew up" from such a form of political performance as a rally. It was there that they got their new "face" to which voters voted. It was a verbal rehearsal of power behavior. The development of democracy is impossible without a sufficient number of language-developed personalities. The epoch of reading from the paper is over. It is no accident that the writers gave a significant number of people's deputies.

Performance is the most massive processes, the most massive strategies of information exchange. And without political performances it is impossible to enter democracy for the population. Here, of course, it is desirable to have another correlation of ritual and improvisation than that which was considered the norm in times of totalitarianism. This program can be displayed based on what is known or unknown to the communicator and the audience about the eventual development of events.

During the election campaigns, the performances are political rallies, meetings with voters, artistic events, sports events, toloches, organized with the support of politics or political forces, etc. The advantage of such non-traditional communication tools for conducting an election campaign is to appeal to the irrational components of social consciousness. They create the illusion of the openness and availability of candidates for voters, use the psychological mechanisms of infection and suggestions that influence the formation of an installation to vote in a way that is necessary for a political entity.

Theatrical performance at all times occupied an important place in public policy. It is no coincidence that political discourse is often described as theatrical metaphors: in the case of doubt in the politics' sincerity assert it as a political farce or "well-rehearsed performance"; failure communication is called the theater of the absurd etc.

According to S. Shomova, the task of political performance is to pesent a bright, memorable information. Performance is rather a way of aesthetizing politics, rather than a means of serious political struggle; it popularizes the leader (party) and, moreover, creates a beautiful image for the media [12, c. 79].

With the help of a political sight, the "jump-off of politics" is carried out through the rational-political component of the consciousness of citizens directly at the level of the irrational-emotional component ("removing the mind straight to the heart"). The spectacle creates the necessary emotional (and not political) state of the spectator-participant and emotional (not political) attraction to political action. Therefore, this effect is short-lived and operates at the level of emotions, and not at the level of stable political attitudes.

Let's recall that political performances are an integral part of the activities of representatives of the parliamentaries and political parties. Striking examples are O. Lyashko (who made shocking destruction of an illegal fence by a tractor, made a slaughter of an illegal casino, brought a cow under the $\mathrm{KM}$, within the framework of an action to raise milk purchasing prices), the "Right sector" (popular lustration of officials using garbage tanks). These are examples of the formation and maintenance of a certain image by politicians.

Performances-protests are widespread in Ukraine today.

Independence Square has twice played the role of a large scene for mass protests-performances. In 2004, the symbols-props of the first Maidan ("Orange Revolution") were orange ribbons, oranges and the pre-election logo of V. Yushchenko - under the name "Tak!". In 2014, the protests of the second Maidan ("EuroMaydan") were followed by "Molotov's cocktail", barricades and tires. The second Maidan demonstrated a whole range of emotional states - everyday life, folk festival, night-time car tire fires, tear gas, military actions, concerts and art exhibitions, flash mobs, the presence of cameras - all this with the help of television and the Internet turned into a real power collision in "total installation", "performance sized as the city".

Special forces "Berkut" were pour on by the soft toys, activists stand in front the special forces with mirrors instead of posters. A distinct bright page belongs to numerous performances with a yellow-and-blue piano decorated with the stars of the European Union, which first appeared at the Presidential Administration at the corner of Bankova Street and Lutheran Street on December 7, 2013. The young Lviv musician Markian Matcheh put the instrument on the border of the special forces and played the 64th opus of Chopin. The idea was to answer art and kindness to violence. 
Maidan, as a major protest political participation, has become a large collection of diverse actions-projects of political performance.

Organizing performances by foreign art groups, with the participation of Ukrainian activists and the public, was characterized by the latest political practice in Ukraine. For example, the Israeli art-group "Public Movement" arranged weekly performances under the general name "Crossroads" devoted to tense political events in Ukrainian society [4].

In 2013, political performances usually had one theme - support for the European integration of Ukraine. For example, the activists of the EuroMaidan city of Odessa built huge letters "We Are" by their bodies holding the Bengal lights lit up in their hands, on the Potemkin Stairs [5]; In Ternopil, 60 participants in the yellow raincoats and with umbrellas performed the dance "Rhythm of Europe" on the central square of the city [6].

In 2014 and early 2015, the most popular theme of political performances was aggression from the side of the Russian Federation. It is worth noting that there is an attempt to attract attention not only Ukrainians but also the whole world to the problems concerning Ukraine. For example, the performance in defense of the Crimea in Ukraine, organized by the writer S. Zhadan and artist V. Klyuzko. The organizers shot a series of photographs with the emblem "Crimea is Ukraine" on the background of works by Van Gogh, Picasso and other famous artists [7]; The delegation of Ukraine to the OSCE made a performance and demonstrated as a protest a photo from the canceled exhibition on Russian aggression in Crimea at the meeting of the Permanent Council of the organization [8].

In the territory of the Museum of the Great Patriotic War in June 2015, a group of people performed the performance "Ukraine without a chains of the Russian world". The naked girl was painted in a yellow-blue color and tied on ropes to the tanks. The girl was wrapped in St. George's ribbons, her mouth was glued with red tape [9].

A large number of breathtaking performances, including politically directed, is conducted by FEMEN's women's organization, which violates certain symbolic frontiers, usy the female body to interest a wide range of problems.

Conclusions. It is important to study the possibilities of performance political communication, advantages and opportunities for its use. Based on the latest trends in the development of public policy, theatricalization and "design" of political reality will become increasingly important for the modern political process, and the perception of political events through the prism of entertainment will inevitably come to new forms and scales.

In our view, political performance in order to effectively achievement of its goals should have the following characteristics:

- development of action in time;

- increasing emotionality;
- game moment of action;

- availability of a script;

- presence of the ultimate goal of the promotion;

- relevance of action;

- as a rule, the protest character of the act;

- certain aesthetics and shoks;

- comprehensibility of the content of the campaign for the audience, etc.

Consequently, at this stage of its formation, political performance as an actual technology of political influence is highly valued and requires its systematization and determination of its laws. According to some researchers, it may not be just a channel of communication, not just a method of influence, but a "third force" in relations between government and society.

\section{REFERENCES}

1. Il'nyts'ka U.V. Perfomansna komunikatsiya yak politychna tekhnolohiya ta skladova imidzhevoyi PR-stratehiyi zbroynykh syl [Performance communication as a political technology and a component of the image PR-strategy of the armed forces]. Nauk. visn. L'viv. in-tu Sukhoput. viys'k im. het'mana P. Sahaydachnoho Nats. un-tu - L'viv. politekhnika. 2009. № 12. S. $189-200$.

2. Kremen' T. Emotsiyna skladova politychnoyi mobilizatsiyi cherez sotsial'ni media [Emotional component of political mobilization through social media]. Naukovi pratsi. Politolohiya. Vyp. 192. Tom 204. C. 72-74.

3. Pocheptsov H. Pablyk ryleyshnz dlya professyonalov [Public relations for professionals]. : http://htbiblio. yolasite.com/resources/Pocheptsov_PR.pdf

4. Public Movement: Performans. 2015. URL: http://artukraine.com.ua/a/public-movement--performans--cepostiyne-doslidzhennya.

5. Performans «My ye». 2015. URL: http:// korrespondent.net/ukraine/politics/3280750-my-ye-napotemkynskoi-lestnytse-proshel-performans-v-podderzhkuevroyntehratsyy.

6. Performans u Ternopoli. 2015. URL: http://korrespondent.net/ukraine/1619029-v-ternopoleustroili-performans-v-podderzhku-es.

7. Performans «Krym - tse Ukrayina». 2015. URL: http://nagg.in.ua/news/100049/\%22Krym---etoUkraina\%22\%3A-Zhadan-ustroil-perfomans-v-odnom-izsamykhizvestnykh-muzeyev-Nyu-Yorka.

8. Performans v OBSYe. 2015. URL: http:// www.eurointegration.com.ua/news/2015/03/20/7032077/.

9. Performans «Ukrayina bez put rosiys'koho svitu». URL: http://www.theinsider.ua/multimedia/ 557ec13d80368/.

10. Semkyn A. Teatr dlya sebya Nykolaya Evreynova [Theater for Nicholas Evreinov]. URL: http://magazines. russ.ru/neva/2005/7/se18.html.

11. Khoma N. Politychnyy perfomans yak postmoderna forma sotsial'noho protestu [Political performance as a postmodern form of social protest]. URL: http://visnyk-psp.kpi.ua/article/viewFile/31199/27808.

12. Shomova S.A. Rytual yly perfomans? (K voprosu o teatral'nukh formakh polytycheskoy kommunykatsyy) [Ritual or performance? (On the question of theatrical 
forms of political communication)]. Zhurnalyst. Sotsyal'nbe kommunykatsyy. 2011. № 4. S. 73-83.

13. Borreca A. Political dramaturgy: a dramurg's (re) view. The Drama Revie. 1993. № 2.

14. Meyer T. Die Inszenierung des Scheins. Voraussetzungen und Folgen symbolisher Politik. Frankfurt/M., 1992. $423 \mathrm{p}$.

15. Meyer T., Kampmann M. Politika als Theater. Die neue Macht der Darstellungskunst. Berlin, 1998.

16. Schechner R. Performance Studies. London: Routledge, 2006. 356 p.

ЛІТЕРАТУРА:

1. Ільницька У.В. Перфомансна комунікація як політична технологія та складова іміджевої PR-стратегії збройних сил. Військ.-наук. вісн. Львів. ін-ту Сухопут. військ ім. гетьмана П. Сагайдачного Нац. ун-ту - Львів. політехніка. 2009. № 12. С. 189-200.

2. Кремень Т. Емоційна складова політичної мобілізації через соціальні медіа. Наукові праці. Серія «Політологія». Вип. 192. Том 204. С. 72-74.

3. Почепцов Г. Паблик рилейшнз для профессионалов. URL: http://htbiblio.yolasite.com/resources/ Pocheptsov_PR.pdf.

4. Public Movement: Перформанс. 2015. URL: http://artukraine.com.ua/a/public-movement--performans--cepostiyne-doslidzhennya.

5. Перформанс «Ми є». 2015. URL: http:// korrespondent.net/ukraine/politics/3280750-my-ye-napotemkynskoi-lestnytse-proshel-performans-v-podderzhkuevroyntehratsyy.
6. Персорманс у Тернополі. 2015. URL: http:// korrespondent.net/ukraine/1619029-v-ternopoleustroili-performans-v-podderzhku-es.

7. Перформанс «Крим - це Україна». 2015. URL: http://nagg.in.ua/news/100049/\%22Krym---etoUkraina\%22\%3A-Zhadan-ustroil-perfomans-v-odnom-izsamykhizvestnykh-muzeyev-Nyu-Yorka.

8. Перформанс в ОБСє. 2015. URL: http:// www.eurointegration.com.ua/news/2015/03/20/7032077/.

9. Перформанс «Україна без пут російського світу». URL: http://www.theinsider.ua/multimedia/ 557ec13d80368/.

10. Семкин А. Театр для себя Николая Евреинова. URL: http://magazines.russ.ru/neva/2005/7/se18.html.

11. Хома Н. Політичний перфоманс як постмодерна фрорма соціального протесту. URL: http://visnyk-psp.kpi.ua/article/viewFile/31199/27808.

12. Шомова С. А. Ритуал или перфоманс? (К вопросу о театральных формах политической коммуникации). Журналист. Социальные коммуникации. 2011. № 4. С. 73-83.

13. Borreca A. Political dramaturgy: a dramurg's (re) view. The Drama Revie. 1993. № 2.

14. Meyer T. Die Inszenierung des Scheins. Voraussetzungen und Folgen symbolisher Politik. Frankfurt/M., 1992. $423 \mathrm{p}$.

15. Meyer T., Kampmann M. Politika als Theater. Die neue Macht der Darstellungskunst. Berlin, 1998.

16. Schechner R. Performance Studies. London: Routledge, 2006. 356p.

\section{Політичний перформанс як технологія впливу}

Макаренко Лілія Петрівна

кандидат політичних наук, докторант кафедри політичних наук

Київського національного університету імені Тараса Шевченка,

вул. Володимирська, 64/13,

Київ, Україна
У статті розглядається політичний перформанс як фрорма соціального протесту, а також як засіб фрормування та підтримки іміджу політиків, здебільшого епатажного. З'ясовуються його особливості й умови ефективності. Серед особливостей ключове місце належить видовищності, апеляції до емоцій і залученню до дійства глядачів. Серед умов есрективності - актуальність дії, як правило, протестний характер акту, певна естетичність і епатажність, зрозумілість змісту акції для аудиторії. Робиться висновок: театралізація й «конструювання» політичної дійсності набуватимуть зростаючої значущості для сучасного політичного процесу, а сприйняття політичних подій через призму видовищності та розважальності неминуче набудуть нових фором і масштабів.

Ключові слова: політичний перорорманс, технологія впливу, протест, імідж, театралізація політики. 